\title{
Human Rights, Freedoms and the Limits of Their Limitation in a Time of Pandemic
}

\author{
Karin Vrtíková ${ }^{1}$ \\ ${ }^{1}$ Faculty of Law, Trnava University in Trnava, Slovak Republic
}

\begin{abstract}
There can be no doubt that the coronavirus pandemic has had an impact on all countries and regions all over the world, as well as on all aspects of human life. In a crisis situation of such a type, not only human health is endangered, but also civil and democratic rights are restricted by means of "temporary" measures taken by executive or legislative power, which may restrict human rights excessively or by "failing" to take suitable measures, the interference with human rights may be suppressed. Although both international law and national legal systems allow restriction of these rights to certain extent with the aim to protect public health, many regimes abuse the pandemic to obscure their systematic restrictions going beyond the frame of the current situation. The aim of the presented article is to provide a factual view of the current situation in our territory, which in our opinion is not legally and socially sustainable in the long time. We will legally substantiate our views and express them as we see fit, based on the principles of democratic establishment of our society.
\end{abstract}

Keywords: democratic society, pandemic, human rights, emergency situation

\section{Introduction}

As Brumlik (2020) states, the ideas related to human rights and liberty and their protection has been undergoing many changes. The ideas have developed from the past to their current form based on general principles of the development of the society and the bebaviour of individuals. They appeared mostly where the human rights and liberties were being violated. 
The same view is shared by Brown (2016), who mentions that the development of the issue of human rights and liberties has gone a long and often dramatic way. According to Ismailee (2019), these concept are currently encountered almost every day and practically everywhere. Each undue interference in these fundamental rights thus results in immediate condemnation either by people or by state. To prevent the violation of fundamental human rights and liberties or at least to limit it as much as possible, it was and it still is necessary to establish these rights, to characterize them and enshrine them in relevant documents, based on which it will be possible to monitor the compliance with these rights (Ife, 2012).

Sneh (2011) claims that mainly after the Second World War, all the inhabitants of the globe realized the meaning of the word peace. They wanted to live in peace, without fear, and therefore they were aware of the need to create a set of rules that would apply to all states and belong to all the people of the world. According to McFarland (2017), this set of rights, which presupposes a dignified life, is called the Universal Declaration of Human Rights, which has thirty articles. The Declaration adopted by the General Assembly of the United Nations, 10 December 1948 in Paris, although not a binding document, ie does not have the force of a treaty or law, is a political text that expresses values associated with respect for and protection of human dignity. Kuzelewska and Tomaszuk (2020) state that it is the best known and most cited document on human rights in the world. All the lists of human rights contained in international and national documents adopted after 1948 have their origins in it. Human rights are the rights of every human being, regardless of their race, religion, nationality or skin color. They are non-removable, inalienable, nonexpiring and irrevocable (Maia and Pontin 2018). According to Zandy (2019), democracy has not worked / does not work in totalitarianism, and this fact is known to us from the recent past. It is the government of one person, group or political party that has suppressed / suppresses human rights in order to usurp such a position. We have the best chance of respecting human rights directly in a democracy. Here, it might seem that there is a general understanding in the world of what human rights are, how they need to be respected, protected, supported and promoted. Perhaps we could afford to think that the representatives we have elected know the meanings of the words freedom, equality, dignity and solidarity - principles of value that should form the basis of human rights. A healthy and prosperous state operates on democratic principles. Unfortunately, I dare to question whether this is the case in the current situation. As Riccardi (2019) states, only since the Enlightenment revolution in the 18th century equality and freedom of all people began to be seen as a fundamental and necessary element of the rule of law. From the 20th century the demand for freedom and equality has also begun to be enforced in international documents. Why do I mention that? Because the Slovak Republic is, in the sense of the Constitution of the Slovak Republic, a democratic and legal state that is not bound by any ideology. It is necessary to realize that even the most perfect rule of law interferes with the fundamental rights and freedoms of its citizens. We do not dwell on the restriction in the form of stopping at a red light at a traffic light or not parking in places reserved for the severely disabled if I do not have such a right. The state regulates me, but 
I accept it as a general rule for the good of me but also for society. But what has happened in recent months, when even the most obedient of the obedient refuse to obey orders?

\section{Methods and Data}

\section{Emergency vs. emergency situation}

As we know, in Slovakia, an emergency situation was first declared in accordance with the provisions of $\S 3$ par. 1 of Act no. 42/1994 Coll. on Civil Protection of the Population as amended (hereinafter referred to as the "Civil Protection of the Population Act") "This is a period of threat or period of impact of an emergency on life, health or property, which is declared under the Civil Protection Act; during an emergency, measures are taken to save lives, health or property, to reduce the risks of danger or to the activities necessary to prevent the spread and effects of the emergency". An emergency situation is the result of an emergency event. An extraordinary event is, for example, a natural disaster, an accident, but also a threat to public health II. degree. Only for the sake of complexity, we add that the Government of the Slovak Republic on March 12, 2020 due to the threat of public health of the 2nd degree according to $\S 48$ par. 2 letter a) of the Public Health Protection Act, in connection with the occurrence of a communicable disease above the expected level and the need to take measures pursuant to $\S 6$ and $\S 9$ of the Civil Protection Act, declared an emergency situation in the Slovak Republic pursuant to $\S 8$ of the Civil Protection Act population (Government Resolution no. 111/2020). An extraordinary situation is declared and revoked by the Government of the Slovak Republic if the extent of the endangered or affected area exceeds the territorial district of the region.

Subsequently, in a few days, the Government of the Slovak Republic declared a state of emergency, specifically on 16.03.2020, and it ended on the 90th day, i.e. 13.06.2020. However, it remains an indisputable fact that the extraordinary situation persists, as in the sense of the Civil Protection Act, an unlimited period of course can last, of course, under the conditions of compliance with $\S 3$ par. 1 of the Act in question. De iure, therefore, from June 14, 2020, we had "only" an extraordinary situation in Slovakia, during which the legal regulation of the Civil Protection Act was to be followed.

Subsequently, a state of emergency was again declared in the entire territory of our republic, from 1.10.2020 for 45 days, ie until 14.11.2020. As we all know at the time of writing, the state of emergency was again extended for another 45 days, i. from 15.11.2020 to 29.12.2020.

The first and most important is the fact of the legitimacy of the declaration of a state of emergency. According to Art. 5 par. 1 of the Constitutional Act no. 227/2002 Coll. on State Security in Time of War, State of War, State of Emergency: (hereinafter referred to as the "State Security Act") "The Government may declare a state of emergency only on condition that the life and health of persons has been or is imminent, even in a causal connection with the occurrence of a pandemic, the environment or the threat to significant property values as a result of a natural disaster, catastrophe, industrial, transport or other operational 
accident; a state of emergency may be declared only in the affected or in imminent territory. "

It is important to fulfill the two characters that are contained in this sentence and are key to us. The first sign is the condition of an immediate threat to the life or health of persons in connection with the occurrence of a pandemic. However, it must not be forgotten that the last part of the paragraph in question, namely that 'a state of emergency may be declared only in the affected area or in the immediately endangered area'. It must be admitted here that a fundamental problem comes to the fore, which the Government of the Slovak Republic does not respect and in which the principle of proportionality is violated, because in the current situation the public interest in protecting life and health decides, I dare say does not exceed the individual rights of individuals.

According to Art. 5 par. 2 of the Constitutional Act in question, it is possible to "Declare a state of emergency to the necessary extent and for the necessary time, for a maximum of 90 days". Since the fact is that the requirement of necessity is not defined anywhere, it is naturally necessary to proceed from the usual interpretation of that word ${ }^{1}$. Therefore, if something is to fulfill the attribute of necessity, the absolute need of the given state or restriction must apply. Looking at the headless prolongation of the state of emergency in the entire territory of the Slovak Republic, the fulfilled aspect of necessity does not come to me. I agree with the opinion of experts who have repeatedly called for the illegality of nationwide restrictions and have proposed the application of strict restrictions to those territories that fulfill the attribute of necessity. Thus, if the outbreak is concentrated in only one district, the requirement of necessity means that the government should declare a state of emergency not for the entire territory of the republic, but only for this particular district. If the virus and its consequences could be removed in a month, it would run counter to the need for the emergency to last for two months.

What scares me, as a lawyer, is the apparent bending of the law that we are witnessing, and in which everyone, even those with a degree from law university, pretends that it does not exist. The most professional, who, as guardians of justice and justice, should pay attention to the observance of the constitution and laws, either hide their heads in the sand or, in the worst case, instead of correcting the situation de lege lata, propose changes to laws and the constitution itself.

On the other hand, it is necessary to admit a certain leniency, because at stake it is the most valuable thing we have. No one counted the situation regarding the coronavirus pandemic. No one knew how to fight it, how best to protect the lives and health of the population with the lowest possible devastation consequences. But shouldn't the just as difficult period that we are currently going through not just us, but the whole world, a reason to postpone all conflicts and hate speech? I firmly believe that the majority will agree with me. On the other hand, how to achieve this? It is not easy to be at the head of a

${ }^{1}$ According to the synonymous dictionary, the meaning of the word necessary means, such) 1) which must be absolutely necessary, necessary, such, 2) which cannot be avoided, which must become, inevitable. 
company in a situation like this. People are angry, passions are escalating and the situation is becoming socially unsustainable.

Breaking the gate, breaking interpretations, throwing cobblestones or public wording are not acceptable in a democratic society to express legitimate disagreement. I do not agree with the situation we witnessed a few weeks ago. So let's realize that aggression is not the way out of problems.

I dare say that due to the result of comprehensive testing 2 that we had in Slovakia, the situation is not such that we can legally meet the conditions of Article 5 para. 2 of the State Security Act in time of war, state of war, state of emergency and state of emergency. I unequivocally consider that the government does not respect the constitutional law in question and thus restricts people to their personal freedom. My view is in line with the analyzes of leading constitutional lawyers. I will quote former vice-president of the Constitutional Court of the Slovak Republic Eduard Barány, who said the following about the current situation: "The claim that widespread coronavirus testing will be voluntary and at the same time force people who cannot be tested to remain in domestic quarantine is a propaganda lie. It is a fraud". Constitutional lawyer Peter Kresák also described the government's sanctions as a" constitutional problem ". He expressed the belief that if this sanction remained there, it would be challenged very quickly in the Constitutional Court. Is it possible that so few people perceive this enormous injustice? Is it possible that so few people realize that intimidation and threats are not the right way out of the crisis?

Since the beginning of the coronavirus pandemic, we have had limited rights and freedoms under this law, with the government declaring a state of emergency. At present, however, I do not share the view of our executive power, and I argue that there are no legal and legitimate reasons for the state of emergency to continue throughout the territory of our republic. I boldly argue that in the proportionality test, such a state of emergency for all spheres of social life and declared throughout the territory of the Slovak Republic would not pass.

\section{Results}

\section{Legality of anti-epidemiological measures, yes or no?}

One of the other aspects with which the legal community in particular should have a problem is the legality of anti-epidemiological measures issued by the Chief Hygienist of the Slovak Republic. We are faced with another doubt whether the person is entitled by law to issue such measures in the form of decrees, resp. if so, who has given such strong power into the hands of one man?

\footnotetext{
2 Within the area testing carried out on 31 October 2020 and 1 November 2020, out of the number of 3,625,332 tested citizens of the Slovak Republic, 38,359 citizens were evaluated as positive for COVID-19. This is 1.06 percent of positively tested citizens who are in quarantine (in the 2nd round on 7-8 November 2020 in 13 districts, out of 2,044,855 people tested, 13,509 were positive, which represents 0.66 percent).
} 
Throughout this situation, I have not allowed myself to disparage the need for increased protection of public life and human health. I'm just used to it and it comes natural to me to ask questions and look for adequate answers. If we are to have limited basic human rights and freedoms, guaranteed not only by the Constitution of the Slovak Republic but also by international documents superior to it, I want to know who and on what basis restricts those rights, whether he has a legal right to the restriction and if he has it, or the legitimacy of the monitored the goal cannot be achieved even by less serious intervention. You may have just said to yourself that I am asking myself unnecessarily many questions, that I should simply give in and "walk with the crowd", but this is contrary to my convictions. I think that it is definitely necessary to discuss the situation, look for the closest possible intersections with the law and other legal regulations. It is necessary to listen to experts, follow their recommendations and not testify their work.

One of the most acute problems seems to me to be the lack of competence of the authority issuing a large part of anti-epidemiological measures. As I have said several times, and what needs to be constantly remembered, the Slovak Republic is a democratic and legal state. A well-governed state and a well-governed society are based on two basic building blocks, namely democracy and expertise. We agree with Drgnonec, who argues that a democratic state is a well-organized and governed state based on a balance of democracy and expertise (Drgonec, 2015, p. 217). The state is the guarantor of respect for human rights, their application and enforcement, if it adopts laws protecting and promoting human rights, if its representatives themselves observe the law and respect the constitution.

Here we must always proceed from the basic rule stated in the Constitution of the Slovak Republic, which in Art. 2 par. 2 states that state bodies may act only on the basis of the Constitution, within its limits and to the extent and in the manner provided by law. Therefore, we must always examine which authority issued the decision and according to which law. It is the law that can give us an answer as to whether or not it has the authority to do so. Article 17 of the Constitution of the Slovak Republic stipulates that personal liberty is guaranteed and no one may be deprived of his liberty other than for reasons and in the manner provided by law.

Paradoxically, the situation for me is when decrees issued by the Public Health Office of the Slovak Republic (hereinafter "PHO SR") are built to the legal level, without any legal justification, I dare say, wrong. Is it not a violation of the law to issue decisions of state bodies in which the competences of the given issuing body and the procedural procedure itself are circumvented? Does the Chief Hygienist, as a representative of the Public Health Office, have a mandate to issue generally binding legal regulations? I base my opinion again on the legal situation in our country.

Decrees of the PHO SR, which restrict the fundamental rights and freedoms of individuals, are ordered by the PHO SR on the basis of $\S 59 \mathrm{~b}$ par. 1 (If it is necessary to order measures pursuant to $\S 12$ or $\S 48$ par. 4 in the whole territory of the Slovak Republic, a certain part of its territory or for a group of persons other than individually designated persons, shall 
be ordered by the Ministry of Health [ $\$ 4$ par. 1 letter g)], the Public Health Office [ $\$ 5$ par. 4 letter $\mathrm{k}$ )] or the regional public health office [ $\S 6$ par. 3 letter e)] by generally binding legal regulation.) z. no. 355/2007 Coll. on the Protection, Promotion and Development of Public Health and on the Amendment of Certain Acts (hereinafter referred to as the "Public Health Act"). Here we see that the Ministry of Health of the Slovak Republic, PHO SR and the regional public health office may issue generally binding legal regulations if necessary, in the form of measures called decrees, which enter into force on the day of their promulgation in the Government Gazette. There would be nothing illegal about this fact if the Ministry of Health of the Slovak Republic itself amended the Act on Public Health, specifically the amendment to Act no. 69/2020 Coll. on interim measures in relation to the spread of dangerous diseases of human illness COVID-19 in the field of health care and which amends and supplements certain laws (hereinafter referred to as the "Act on Extraordinary Measures Related to the Dissemination COVID-19 "). , The Ministry of Health of the Slovak Republic is given the opportunity to order measures. "

But let's turn all this information into small pieces. The provision of $\S 48$ par. 4 of the Public Health Act determines the scope of the PHO SR power to issue measures during the so-called threats to public health. At the same time, the Public Health Act does not specify what is specifically considered to be a threat to public health. However, distinguishes between the threat to public health and the threat to public health II. degree. Public health hazards II. degree is definitely more important for the state, which is reflected in the Public Health Act in ust. $\S 48$ par. 5, which fulfills and at the same time orders the PHO SR to, in the event of a threat to the public health II. degree submitted a proposal for the declaration of an extraordinary situation under the Act on Civil Protection of the Population. But we have had an extraordinary situation here since March 12, 2020, and it continues. The following logically follows from this fact. PHO SR did not have to submit a proposal for a declaration of an emergency situation, because it already existed in our territory. But at the same time, with regard to the fact that the extraordinary situation persists, the government of the Slovak Republic and the Ministry of Health were to take over the management measures during the extraordinary situation. as a central body of state administration in the field of health care, under which PHO SR operates as a budgetary organization of the ministry. In view of this, the question is to what extent (and if at all) the PHO SR was (and still is) entitled to issue measures It is during a temporary situation.

\section{Discussion}

By a logical interpretation, I would like to argue that the PHO SR can issue measures in the form of decrees only in the event of a threat to public health of the 1st degree, as in the case of a threat to public health of the 2nd degree this power passes into the hands of the Ministry of Health. There is also a certain withdrawal of competencies of state administration bodies in the field of those from the importance of public health hazards, which has its own economic logic. In the event that there is a risk to public health, it is not 
yet II. level, its tasks are competent to perform directly PHO SR according to $§ 48$ par. 4 Public Health Act. In the event that the threat to public health reaches II. degree, PHO SR should have its finances according to $\S 48$ par. 5 to the extent that it submits a proposal for the promulgation of an extraordinary situation, and thus fulfills its complex and further, it should be followed according to the Code of Civil Protection, as it also follows from the legal adjustment reports. ${ }^{3}$ This at the same time emphasizes the important competencies in the dependence of the lot from the seriousness of the situation, which confirms it is my partial belief that the Public Health Office is not entitled to issue the PHO SR Measures to the extent that it can issue them during the intermittent situation of health education. The Constitution of the Slovak Republic in Art. 123 also refers to such a situation when it claims that all other executive bodies may issue a secondary legal act only if the law explicitly states which public authority and to what extent regulates the issue which is the subject of the statutory regulation. We have such a law here. Specifically, the above-mentioned Act no. 69/2020 Coll., Which was granted this authority to the Ministry of Health of the Slovak Republic. So why isn't this legal option, this legitimate right, being used, but are we involved in exceeding legal competences?

We will remain with anti-epidemiological measures for a while. As we have been overwhelmed by them since the beginning of the pandemic, it is necessary to adequately express the legal opinion on their legality and thus define or draw attention to possible legal shortcomings.

We have already talked about the state of emergency above. In principle, it is declared by the Government of the Slovak Republic on the condition that it has occurred or there is an imminent risk that the The number and health of persons, among other things, also in the causal connection with the emergence of pandemic.

The procedure for the authorities of public power during the emergency status is replaced by Act no. 387/2002 Coll. on the Management State in Crisis Situations Outside the Time of the War and the Military Status (hereinafter referred to as the "Crisis Act"). It regulates, inter alia, the powers of public authorities in the management of the state in crisis situations outside the time of war and military status, the rights and obligations of legal entities and natural persons in preparing for crisis situations outside the time of war and military status and their resolution and sanctions for breaches of obligations by law. The Act further regulates crisis management bodies including the Government of the Slovak Republic, the Security Council of the Slovak Republic, ministries and other central state administration bodies, the National Bank of Slovakia, the Regional Security Council, the District Office, the District Security Council and the municipality. The Office of Public Health among these bodies, I think that everyone recognizes, is not and now is not even the body of the crisis management, this is, after all, the Ministry of Health and, of course, the government of the Slovak Republic.

\footnotetext{
${ }^{3}$ Reasonable report to Act no. 69/2020 Coll. on interim measures in relation to the spread of dangerous human diseases COVID-19 in the field of health care and which amends and supplements some laws.
} 
We believe that the legislator has logically defined the hierarchy of state administration bodies and thus strengthened the function of their competence. A priori, we do not see the importance of the Government of the Slovak Republic and the Ministry of Health issuing measures in times of emergency and emergency situation if this competence could be performed on their behalf by the Public Health Office. We would also like to emphasize the fact that in the event of a declaration of a state of emergency, it seems to us justified that the Government of the Slovak Republic and the Ministry of Health have strengthened powers.

It is therefore up to each of us to deal with the above, but we are of the opinion that the legality and legitimacy of the PHO SR measures are contrary to constitutional principles and conflict with respect for fundamental rights and freedoms, division of power and, last but not least, the principle of rule of law. Perhaps many will ask themselves whether it is important to deal with what the PHO SR has already issued and declared, to which the citizens of our republic have already submitted, either voluntarily or by force. However, I unequivocally argue that it is precisely in the time and situation in which we find ourselves that the proportional restriction of fundamental rights and freedoms and, in particular, the precise definition of the competence of which body entitled to such principles into human rights is extremely important. Unfortunately, last but not least, we see that the situation with COVID-19 remains serious and therefore our position could at least be stimulating for the future.

\section{Conclusion}

In summary of the above, we would like to state that we do not seek to question the actions of state authorities, but rather to point out that even in such difficult times, state authorities should strictly abide by the law and lead by example. For natural and legal persons, the presumption of knowledge of legal regulations applies (everyone knows the law), the more the competent representatives of these citizens should know it. It is not that the authorities cannot order certain measures, but if they do, let them ensure that the law is observed. Failure to do so will only cause further problems ${ }^{4}$.

In conclusion, we dare to say that in the current situation, when society is struggling with economic as well as social problems, it is necessary to follow the expert opinions and recommendations of scientists and qualified people from the fields of medicine, biology and epidemiology. Undoubtedly one of such are the members of the Slovak Medical Chamber. We should not witness the dishonesty of the scientific leaders ${ }^{5}$, because such a direction could lead us to a society-wide rebellion.

\footnotetext{
${ }^{4}$ An example of one of these problems is France, where the prosecutor's office is already prosecuting the Prime Minister and the Minister of Health for failing to cope with a pandemic during the first wave of coronavirus.

5 An example is Professor Jaroslav Flegr, who is ranked among experts of European format in the field of parasitology and ecology, who often spoke about the Covid-19 pandemic.
} 
The principles of democracy and human rights are not enforced automatically, and we are no longer saying that simply. As we can see, it is not enough to "just" anchor them in the constitution. They must be constantly renewed, enforced and discussed by the right people (competent politicians, constitutional officials, judges, elected representatives at all levels of power). Respect for human rights is a necessary condition for the functioning of democracy and the rule of law, it is a prerequisite for a dignified life for its people.

\section{Acknowledgement}

This work was supported by Slovak Research and Development Agency under the Contract No. APVV-19-0050 entitled: "Criminal protection of liberty".

\section{References}

Act no. 227/2002 Coll. on the Security of the State in Time of War, State of War, State of Emergency as amended.

Act no. 355/2007 Coll. on the Protection, Promotion and Development of Public Health and on the Amendment of Certain Laws.

Act no. 387/2002 Coll. on the State of War in Crisis Situations Outside the Time of the War and the military Status.

Act no. 42/1994 Coll. on Civil Protection of the Population, as amended.

Act no. 460/1992 Coll. The Constitution of the Slovak Republic as amended.

Act no. 69/2020 Coll. on Interim Measures in Relation to the Spread of Dangerous Human Disease COVID-19 in the Field of Health Care and which Amends and Supplements some Laws.

BROWN, G., 2016. The long and influentia. Life of the Universla Declaration of Human Rights, p. 29-38.

BRUMLIK, M., 2020. Regulations on Religious Freedom. From the Universal Declaration of Human Rights to the Judgments of the European Court of Human Rights. Zeitschrift fur Pedagogigk, 66(5), p. 765-766.

DRGONEC, J., 2015. Constitution of the Slovak Republic, Theory and Practice. Bratislava: C.H. Beck.

CZECH REPUBLIC, 2020. Government Resolution no. 111/2020. In: Chamber of Deputies of the Czech Republic. Online, available from https://public.psp.cz/en/sqw/sbirka.sqw?cz=111\&r=2020

IFE, J., 2012. The universal declaration of human rights. Human rights and social work: towards rights-based practice, p. 316-324. 
ISMAILEE, S., 2019. Religious freedom and the universal declaration of human rights. Human Rights Review, 20(2), p. 257-258.

KUZELEWSKA, E. and M. TOMASZUK, 2020. European Human Rights Dimension of the Online Access to Cultural Heritage in Times of the COVID-19 Outbreak. International Journal For The Semiotics Of Law-Revue Internationale De Semiotique Juridique.

MAIA, T. V. and F. PONTIN, 2018. Seventy years of the Universal Declaration of Human Rights. Dialogo, 39, p. 93-96.

MCFARLAND, S., 2017. The Universal Declaration of Human Rights: A tribute to its architects. Public Integrity, 19(2), p. 108-122.

RICCARDI, A., 2019. The Universal Declaration of Human Rights in twenty years of ICC practice: An international law perspective. International Criminal Law Review, 19(6), p. 1057-1080.

SNEH, I., 2011. Human rights today: 60 years of the universial declaration. Human Rights Review, 12(3), p. 409-411.

UNITED NATIONS, 1948. Universal Declaration of Human Rights. Online, available from: https://www.un.org/en/universal-declaration-human-rights/

ZANDY, J., 2019. Universal Declaration of Human Rights. Radical Teacher, 113, p. 54-55.

\section{Contact adress of the author:}

JUDr. Karin Vrtíková, Faculty of Law, Trnava University in Trnava, Koollárova 10, 91843 Trnava, Slovak Republic, kvrtikova@gmail.com 